\title{
A new species of Arenophryne (Anura: Myobatrachidae) from the central coast of Western Australia
}

\author{
Paul Doughty' and Danielle Edwards ${ }^{2}$ \\ Department of Terrestrial Zoology, Western Australian Museum, 49 Kew Street, Welshpool, \\ Western Australia 6106, Australia. Email: Paul.Doughty museum.wa.gov.au \\ ¿School of Animal Biology, University of Western Australia, \\ Crawley, Western Australia 6009, Australia
}

\begin{abstract}
The sandhill frog, Arenophyme rotunda, belongs to a monotypic genus that occurs on the central coast of Western Australia. It has a highly modified body shape with a small head and large front limbs. Members of this species burrows forwards through sand substrates. Here we describe a new species of Arenophyrne from the Geraldton sandplain that occurs to the south of the populations of the type species A. rotunda at Shark Bay. Relative to $A$. rotunda, the new taxon has a more pointed snout, smaller face and eyes, larger hands, rougher dorsal surface and darker colouration that matches the background colour of the sands on which it occurs. Molecular evidence indicates divergence of the two taxa in the late Miocene to early Pliocene, approximately 5-6 mya. The western coast of Australia has a complex biogeographic history owing to geological activity and changes in sea level interacting with extensive sandy areas. Speciation within Arenophyme on the coastal dunes of Western Australia indicates that levels of diversity in subterranean groups there may be underestimated owing to conservative fusiform morphology of burrowing animals.
\end{abstract}

Keywords: cryptic species, frog, fossorial, Geraldton sandplain

\section{INTRODUCTION}

Southwestern Australia is a biodiversity hotspot (Cincotta et al. 2000; Myers et al. 2000), which is the centre of diversity and endemism for many kinds of plants and animals (Hopper et al. 1996; Hopper and Gioia 2004), including several lineages of frogs (Roberts and Watson 1993). Within this region, ancient radiations of species have occurred within the two oldest families of frogs, the Myobatrachidae and Limnodynastidae (Frost et al. 2006). Within the Myobatrachidae, one particular monophyletic lineage contains three related monotypic genera: Arenophryne Tyler, 1976, Myobatrachus Gray, 1841 and Metacrinia Harrison, 1927 (Read et al. 2001). All are restricted to the southwest and have direct-developing young, fossorial habits and do not hop. Metacrinia nichollsi crawls among the moist leaf-litter of the southern forests, whereas Myobatrachus gouldii and A. rotunda have evolved subterranean habits including the evolution of a more fusiform shape (small head, short limbs, flattened body) and burrow forwards through sand. Forwards burrowing in anurans ( $>4000$ species) has evolved independently only a few times: for example, species in the microhylid genera Copiula Mehely, 1901 and Choerophryne Van Kampen, 1914 of New Guinea, Hemisus marmoratus Peters, 1854 from Africa, Rhinophrynus dorsalis Dumeril and Bibron, 1841 from Mexico and Nasikabatrqchus sahyadrensis
Biju and Bossuyt, 2003 of India. Forwards burrowing has presumably arisen only once in the ArenophyrneMyobatrachus lineage (Emerson 1976; Menzies and Tyler 1977; Trueb and Cannatella 1982; Davies 1984; Tyler 1994).

"Cryptic" species are good evolutionary species that are not recognised as such owing to their morphological similarity to one or more described forms (Donnellan et al. 1993). Taxa with conservative morphologies are especially difficult to detect and can only be elucidated with genetic techniques or large series of specimens to enable morphologists to tease out subtle but consistent differences among forms. Homoplastic traits (i.e., widely distributed traits within a lineage) may be the result of adaptive convergence of traits owing to a similar pattern of natural selection acting in similar environments. Species with adaptations to swimming or burrowing are especially likely to harbour cryptic species as external morphology becomes more streamlined to enable the animals to move more efficiently through a liquid medium (i.e, water or sand).

A recent molecular genetic study by Edwards (2007) has revealed significant genetic structuring within Arenophryne. Here, we present a detailed morphological analysis of variation within A. rotunda and describe as new a second species to the south of the populations of A. rotunda from Shark Bay. 


\section{METHODS}

Table 1 shows the morphological variables measured with their definitions and abbreviations. We also calculated the following ratios: HL/SVL, HL/HW, EN/IN, EN/IO, TibL/SVL, TarL/SVL and TarL/TibL. Genetic analyses (Edwards in press) indicated a clear disjunction of lineages within the range of $A$. rotunda occurring between Edel Land and Coolamia Station (Figure 1). We selected approximately 30 adult specimens from within each of the regions identified by the genetic analyses of each taxon for our morphological comparison. Visual examination of the frequency distributions of traits indicated no obvious violations of normality and heteroscedasticity. A 2-way ANOVA of SVL was carried out with region (or "species") and sex as factors. We tested whether there were significant differences of morphological characters with 2-way ANCOVA with species and sex as factors and body size (SVL) as the covariate. When factors or interactions were significant, we present summaries for each category separately in Table 2. All specimens from Western Australian Museum (WAM prefix excluded from registration numbers).

\section{RESULTS}

Table 2 summarises the morphological differences between Arenophyrne from the two regions. Two main differences between the regions were apparent. First, individuals from the southern region had narrower heads, smaller eyes and shorter distances for EN, IO and IN. These characters are likely to be highly correlated with a reduction in head size. Second, frogs from the southern region had significantly larger hands. Several characters displayed complex interactions or were not significant. Females were larger in both taxa, with no difference in body size although the interaction term indicated sex differences were more pronounced in $A$. rotunda. Head length showed significant main effects and interactions, mostly owing to a larger size for $A$. rotunda females. Arm width also showed complex, although subtle, interactions. No characters of the rear limbs differed significantly between the two taxa.

Colouration between the two taxa was also noticeably different. Northern Shark Bay populations are pale white with black flecks (tending to form paravertebral rows) and often some red flecking. In contrast, southern populations are a much darker brown (also with broad darker paravertebral rows and some red flecking) with usually a dark transocular bar present.

Based on the morphological observations presented above and the molecular genetic analysis of Edwards (2007), we describe the southern taxon of Arenophyrne as a new species.

\section{TAXONOMY}

\section{Amphibia}

Family Myobatrachidae Schlegel 1850

Genus Arenophryne Tyler 1976

Arenophryne xiphorhyncha sp. nov.

\section{Southern Sandhill Frog}

Figures 2 and 3

\section{Material examined}

Holotype

Australia: Western Australia: WAM R67321. An adult female collected at Cooloomia Station, Western

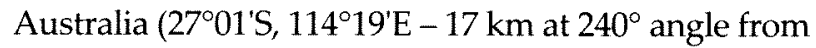

Table 1 Characters measured with abbreviations and explanations.

\begin{tabular}{lll}
\hline Character & Abbrev. & Explanation of Measurement \\
\hline Adults & & \\
\hline Snout-vent length & SVL & From tip of snout to posterior tip of urostyle \\
Inter-limb length & ILL & From axilla to groin \\
Head length & HL & From tip of snout to posterior edge of midpoint of tympanic fold \\
Head width & HW & Width of head at midpoint of tympanic fold \\
Eye-naris distance & EN & From anterior corner of eye to posterior edge of naris \\
Interorbital span & IO & Distance between anterior corners of eyes \\
Internarial span & IN & Distance between inner edges of nares \\
Eye length & EyeL & Anterior to posterior corners \\
Hand length & HandL & Tip of $2^{\text {nd }}$ finger to proximal edge of palmar tubercle \\
Arm width & ArmW & Maximum width of forearm \\
Tibia length & TibL & Measured with leg in natural resting position, from knee to tarsus \\
Tarsus length & TarL & Measured with leg in natural resting position, from proximal end of tarsus to \\
& & proximal edge of inner metatarsal tubercle \\
Foot length & FootL & From tip of $4^{\text {th }}$ toe to proximal end of inner metatarsal tubercle \\
\hline
\end{tabular}




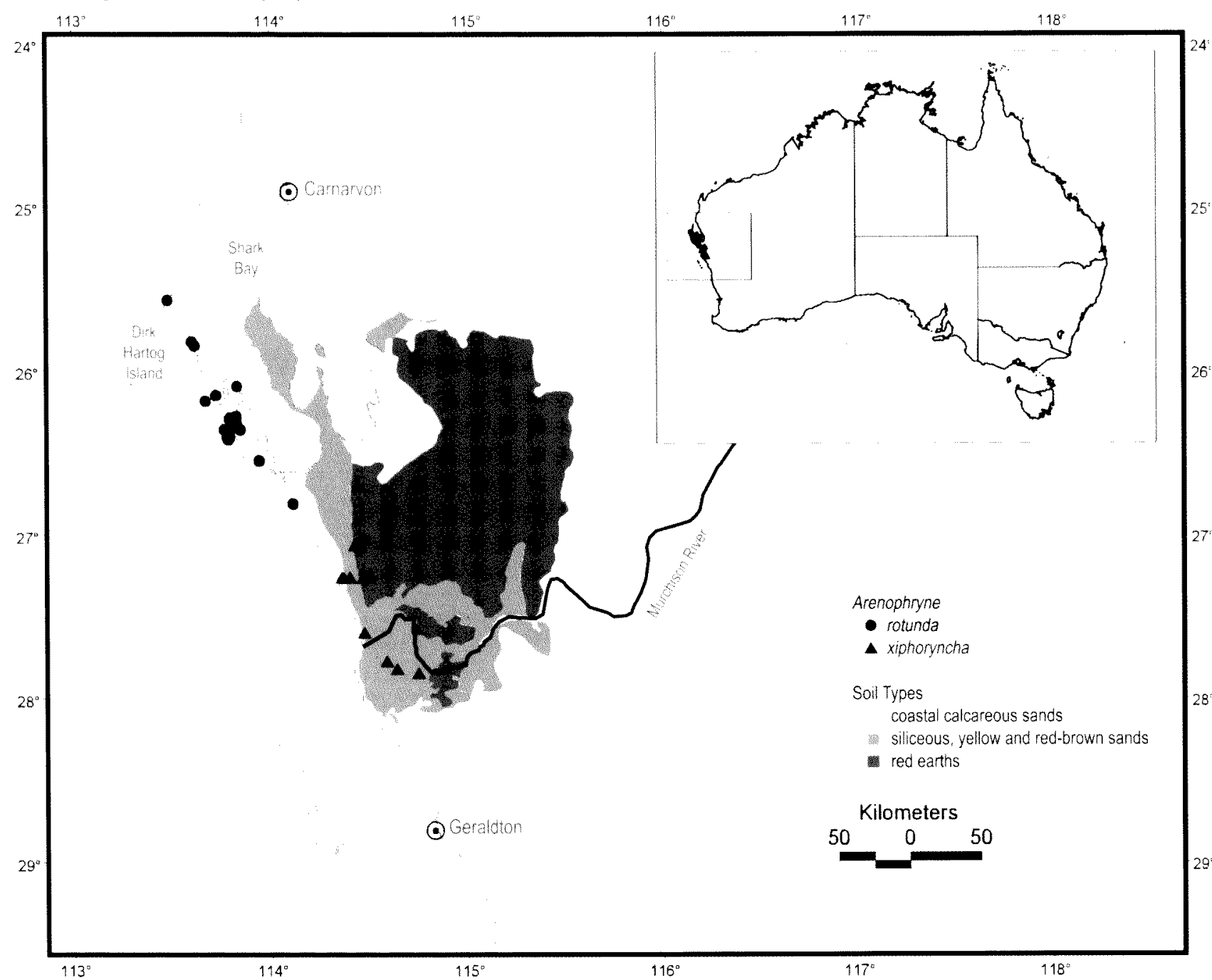

Figure 1 Map of coastal Western Australia showing distribution of Arenophryne rotunda and A. xiphorhyncha sp. nov.

Cooloomia homestead) by J. Rolfe, S. D. Hopper, P. J. Fuller and K. Cashin on 19 September 1979.

\section{Paratypes}

Australia: Western Australia: WAM R67320 and R67323 (females) details as for holotype; R123485 and R126270 (males) $50 \mathrm{~km} N$ Kalbarri - Carnarvon Basin

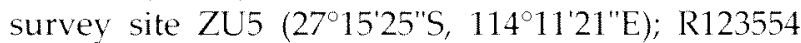
and R126251 (males) $50 \mathrm{~km} \mathrm{~N} \mathrm{Kalbarri-Carnarvon}$ Basin survey site ZU4 (27'15'24"S, 114 9'11"E); R126245 (male) $50 \mathrm{~km} \mathrm{~N} \mathrm{Kalbarri} \mathrm{-} \mathrm{Carnarvon} \mathrm{Basin}$ survey site ZU2 (27 15'41'S, 114.1'48'E); R126261 (female) $50 \mathrm{~km} N$ Kalbarri - Carnarvon Basin survey

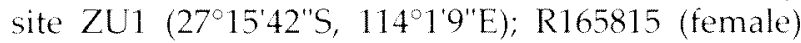
Sandy Junga Pits (27.49'59'S, 11421'53"E); R165821 (female) $10 \mathrm{~km} \mathrm{NW}$ of Murchison House Station

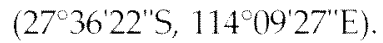

\section{Diagnosis}

A member of the genus Arenophryne based on compressed ovoid body shape, small head with blunt snout with thickened epithelial tissue, short limbs with unwebbed fingers and toes, palmar and plantar surfaces bearing numerous tubercles, tympanum absent, ground colour not yellow or pink, direct developing larvae and forwardburrowing locomotion.

Arenophryne xiphorhyncha is distinguished from A. rotunda by narrower head with sharper canthal region, smaller and less protruding eyes, larger hands and darker colouration.

\section{Description}

\section{Holotype}

Measurements $(\mathrm{mm})$ : SVL -30.0 ; ILL - 15.4; HL 7.9; HW - 10.3; EN - 1.6; IO - 4.2; IN - 2.0; EyeL 2.8; HandL - 6.1; ArmW - 2.8; TibL - 4.4; TarL - 3.8; FootL $-7.1, \mathrm{HL} / \mathrm{SVL}-0.26, \mathrm{HL} / \mathrm{HW}-0.77$, EN/IN $0.80, \mathrm{EN} / \mathrm{IO}-0.38$, TibL/SVL -0.14 , TarL/SVL 0.12 , TarL/TibL -0.86 .

Body dorsoventrally compressed and ovoid when viewed dorsally (Figure 2A). Skin loose with slightly raised bumps and folds scattered along 
Table 2 Summaries of characters and ratios measured for Arenophryne xiphorhyncha and A. rotunda. Mean \pm S.D. (range). $\mathrm{N}=30$ for both taxa unless noted. See Table 1 for abbreviations. SVL was tested with a 2-way ANOVA. 2-way ANCOVAs (factors - species and sex, covariate - SVL) were carried out (see text for explanation) and reported in the last column. Unless noted, sex and all species $X$ sex interaction terms were not significant with alpha $=0.05$. Key: NS - not significant: $\mathrm{P}>0.10,\left(^{*}\right) 0.05<\mathrm{P}<0.10,{ }^{*} \mathrm{P}<0.05,{ }^{*} \mathrm{P}<0.01$, *** $\mathrm{P}<0.001, * * * * \mathrm{P}<0.0001$.

\begin{tabular}{|c|c|c|c|}
\hline Character & $\begin{array}{l}\text { A. xiphorhyncha } \\
\qquad \mathrm{N}=30\end{array}$ & $\begin{array}{l}\text { A. rotunda } \\
\mathrm{N}=30\end{array}$ & Statistics \\
\hline SVL & $\begin{array}{c}\text { Female }(\mathrm{N}=20) \text { : } \\
30.2 \pm 2.8 \\
(26.0-36.0) \\
\text { Males }(\mathrm{N}=10) \\
28.9 \pm 1.7 \\
(26.5-32.0)\end{array}$ & 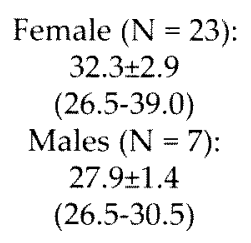 & $\begin{array}{r}\text { Spp:: } F_{1,56}=0.445^{\mathrm{Ns}} \\
\text { Sex: } F_{1,56}=14.811^{* * *} \\
\text { Spp. X Sex: } F_{1,56}=4.278\end{array}$ \\
\hline ILL & $\begin{array}{c}12.5 \pm 2.1 \\
(9.5-17.1)\end{array}$ & $\begin{array}{c}13.8 \pm 2.0 \\
(9.2-19.7) \\
N=28\end{array}$ & $\begin{array}{l}\text { Spp:: } F_{1,54}=2.704^{N S} \\
\text { SVL: } F_{1,54}=47.8^{* \cdots \cdots}\end{array}$ \\
\hline HL & $\begin{array}{c}\text { Female }(\mathrm{N}=20): \\
8.0 \pm 0.4 \\
(7.2-8.8) \\
\text { Males }(\mathrm{N}=10): \\
7.9 \pm 0.6 \\
(6.9-8.7)\end{array}$ & $\begin{array}{c}\text { Female }(\mathrm{N}=21) \text { : } \\
8.7 \pm 0.6 \\
(7.4-9.6) \\
\text { Males }(\mathrm{N}=7): \\
7.7 \pm 0.3 \\
(7.2-8.1)\end{array}$ & $\begin{array}{c}\text { Spp.: } F_{1,53}=4.362^{*} \\
\text { Sex: } F_{1,53}=2.531^{*} \\
\text { Spp. } X \text { Sex: }^{*} F_{1,53}=5.167 \\
\text { SVL: } F_{1,53}=35.35^{* * *}\end{array}$ \\
\hline HW & $\begin{array}{c}9.6 \pm 0.6 \\
(8.6-10.9)\end{array}$ & $\begin{array}{c}10.5 \pm 0.6 \\
(9.1-11.8) \\
N=28\end{array}$ & $\begin{array}{l}\text { Spp.: } \mathrm{F}_{1,54}=44.7^{* * *+} \\
\text { SVL: } \mathrm{F}_{1,54}=30.3^{*+*+}\end{array}$ \\
\hline EN & $\begin{array}{c}1.6 \pm 0.2 \\
(1.4-2.0)\end{array}$ & $\begin{array}{c}1.9 \pm 0.2 \\
(1.7-2.4)\end{array}$ & $\begin{array}{l}\text { Spp.: } F_{1,56}=30.5^{* * * *} \\
\text { SVL: } F_{1,56}=6.90^{\circ}\end{array}$ \\
\hline IO & $\begin{array}{c}4.2 \pm 0.2 \\
(3.8-4.8)\end{array}$ & $\begin{array}{c}5.0 \pm 0.3 \\
(4.5-5.7)\end{array}$ & $\begin{array}{l}\text { Spp.: } F_{1,56}=207.8^{* * * *+} \\
\text { SVL: } F_{1,56}=42.9^{* * * *}\end{array}$ \\
\hline IN & $\begin{array}{l}2.0 \pm 0.2 \\
(1.7-2.2)\end{array}$ & $\begin{array}{c}2.2 \pm 0.2 \\
(1.8-2.9)\end{array}$ & $\begin{array}{l}\text { Spp.: } F_{1,56}=27.8^{* * * *} \\
\text { SVL: } F_{1,56}=16.6^{* * * *}\end{array}$ \\
\hline EyeL & $\begin{array}{c}2.9 \pm 0.2 \\
(2.4-3.4)\end{array}$ & $\begin{array}{c}3.4 \pm 0.3 \\
(2.8-4.2)\end{array}$ & $\begin{array}{l}\text { Spp.: } F_{1,56}=37.2^{* * * *} \\
\text { SVL: } F_{1,56}=16.1^{* * *}\end{array}$ \\
\hline ArmL & $\begin{array}{c}\text { Female }(\mathrm{N}=20): \\
3.1 \pm 0.4 \\
(2.4-4.0) \\
\text { Males }(\mathrm{N}=10): \\
2.5 \pm 0.3 \\
(2.0-2.8)\end{array}$ & $\begin{array}{c}\text { Female }(\mathrm{N}=23) \text { : } \\
3.0 \pm 0.3 \\
(2.5-3.7) \\
\text { Males }(\mathrm{N}=7): \\
2.6 \pm 0.3 \\
(2.0-2.9)\end{array}$ & $\begin{array}{c}\text { Spp.: } \mathrm{F}_{1,55}=0.533^{\mathrm{NS}} \\
\text { Sex: } \mathrm{F}_{1,55}=8.141^{* *} \\
\text { Spp. } X \text { Sex: } \mathrm{F}_{1,55}=5.167 \\
\text { SVL: } \mathrm{F}_{1,55}=18.85^{* * *}\end{array}$ \\
\hline HandL & $\begin{array}{c}5.9 \pm 0.4 \\
(5.0-6.8)\end{array}$ & $\begin{array}{c}5.6 \pm 0.4 \\
(4.8-6.5) \\
N=29\end{array}$ & $\begin{array}{l}\text { Spp:: } F_{1,55}=18.3^{*+*+*} \\
\text { SVL: } F_{1,55}=7.36^{* *}\end{array}$ \\
\hline TibL & $\begin{array}{c}5.6 \pm 0.6 \\
(4.4-7.0) \\
\mathrm{N}=28\end{array}$ & $\begin{array}{c}5.6 \pm 0.7 \\
(4.4-7.2) \\
N=25\end{array}$ & $\begin{array}{l}\text { Spp.: } F_{1,49}=0.358^{N S} \\
\text { SVL: } F_{1,49}=11.179^{* *}\end{array}$ \\
\hline TarL & $\begin{array}{c}3.9 \pm 0.5 \\
(3.0-5.0) \\
N=28\end{array}$ & $\begin{array}{c}3.8 \pm 0.5 \\
(2.7-4.6) \\
N=25\end{array}$ & $\begin{array}{l}\text { Spp.: } F_{1,49}=0.103^{\mathrm{NS}} \\
\text { SVL: } F_{1,49}=2.008^{\mathrm{NS}}\end{array}$ \\
\hline FootL & $\begin{array}{c}7.2 \pm 0.5 \\
(6.1-8.4) \\
N=27\end{array}$ & $\begin{array}{c}7.4 \pm 0.6 \\
(6.3-8.4) \\
N=22\end{array}$ & $\begin{array}{l}\text { Spp.: } F_{1,45}=0.033^{\mathrm{NS}} \\
\text { SVL: } F_{1,45}=11.015^{*}\end{array}$ \\
\hline
\end{tabular}


Table 2 (cont.)

\begin{tabular}{|c|c|c|c|}
\hline Character & $\begin{array}{c}\text { A. xiphorhyncha } \\
\mathrm{N}=30\end{array}$ & $\begin{array}{l}\text { A. rotunda } \\
\mathrm{N}=30\end{array}$ & Statistics \\
\hline $\mathrm{HL} / \mathrm{SVL}$ & $\begin{array}{c}0.27 \pm 0.02 \\
(0.23-0.29)\end{array}$ & $\begin{array}{c}0.27 \pm 0.02 \\
(0.24-0.30) \\
N=28\end{array}$ & \\
\hline HL/HW & $\begin{array}{c}0.83 \pm 0.03 \\
(0.77-0.90)\end{array}$ & $\begin{array}{c}0.80 \pm 0.04 \\
(0.73-0.87) \\
N=28\end{array}$ & \\
\hline $\mathrm{EN} / \mathrm{IN}$ & $\begin{array}{c}0.83 \pm 0.07 \\
(0.71-0.95)\end{array}$ & $\begin{array}{c}0.85 \pm 0.10 \\
(0.66-1.20)\end{array}$ & \\
\hline $\mathrm{EN} / \mathrm{IO}$ & $\begin{array}{c}0.39 \pm 0.04 \\
(0.33-0.40)\end{array}$ & $\begin{array}{c}0.38 \pm 0.03 \\
(0.33-0.46)\end{array}$ & \\
\hline TibL/SVL & $\begin{array}{c}0.19 \pm 0.02 \\
(0.14-0.24) \\
N=28\end{array}$ & $\begin{array}{c}0.18 \pm 0.02 \\
(0.14-0.22) \\
N=25\end{array}$ & \\
\hline TarL/SVL & $\begin{array}{c}0.13 \pm 0.02 \\
(0.10-0.17) \\
N=28\end{array}$ & $\begin{array}{c}0.13 \pm 0.02 \\
(0.09-0.17) \\
N=25\end{array}$ & \\
\hline TarL/TL & $\begin{array}{c}0.70 \pm 0.08 \\
(0.66-0.88) \\
N=28\end{array}$ & $\begin{array}{c}0.69 \pm 0.09 \\
(0.52-0.85) \\
N=25\end{array}$ & \\
\hline
\end{tabular}

body and tending to form vertebral, paravertebral and dorsolateral ridges; rugose along lateral surfaces.

Head small. Snout narrow with moderate canthus rostralis (Figure 3C). Thickened epithelial stratum corneum covers the end of the snout. Eyes not projecting far beyond outline of head or body. Nostrils near end of snout and directed upwards. Mouth wide, terminating below eyes. Vomerine teeth absent. Tongue narrow and long. No visible tympanum, but with distinct tympanic fold posterior to eye. Raised skin with glandular appearance between mouth and forelimbs (Figure 3A). Urostyle not projecting; cloaca directed posteriorly and downwards.

Limbs massive and extremely short. Forelimbs stout and covered in loose skin with elbow barely discernible. Hands robust with first three fingers extremely thickened and numerous tubercles scattered on palm including large palmar tubercle; $4^{\text {th }}$ finger extremely reduced (Figure 3F). Fingers with strong fringes, including ridges formed on the sides of the hand along the palm and inner edge of $1^{\text {th }}$ finger and outer edge of $4^{\text {th }}$ finger. Finger length: $2>3>1>4$. Legs also stout and thick and covered with loose-fitting skin. Feet robust with strong fringes and numerous tubercles on the plantar surface (Figure 3G). Toe length: $4>3>5>2>1$ ( $1^{\text {" t }}$ toe extremely reduced to almost the size of the plantar tubercle).

\section{Colouration in preservatize}

Light brown dorsum with darker dorsolateral stripes. Dark grey patches on shoulders. Top of head pale with almost white snout. Limbs cream with pale digits. Belly pale brown with lighter cream colour towards flanks; chin cream (umpigmented).

\section{Variation}

Females were larger than males (Table 2), as is the case for most anurans. A lack of smaller size classes precluded an analysis of size at maturity. Overall, there was little variation in head or limb proportions among individuals, including no pronounced sex-based differences in shape. More pronounced body shape differences among the preserved specimens was due to the fullness of the gut. Many individuals had guts filled exclusively with ants which gave them a plump appearance. Individuals varied in the rugosity of the skin from nearly smooth to raised folds of skin tending to form ridges along the dorsolateral stripes (as in the holotype). Likewise, ventral surfaces ranged from almost smooth to moderately granular, although this appeared to vary with the preparation and age of specimens.

\section{Colour in life}

Live A. xiphorhyncha (Figure 2A) have a medium to dark brown dorsum with pale limbs, flanks and 

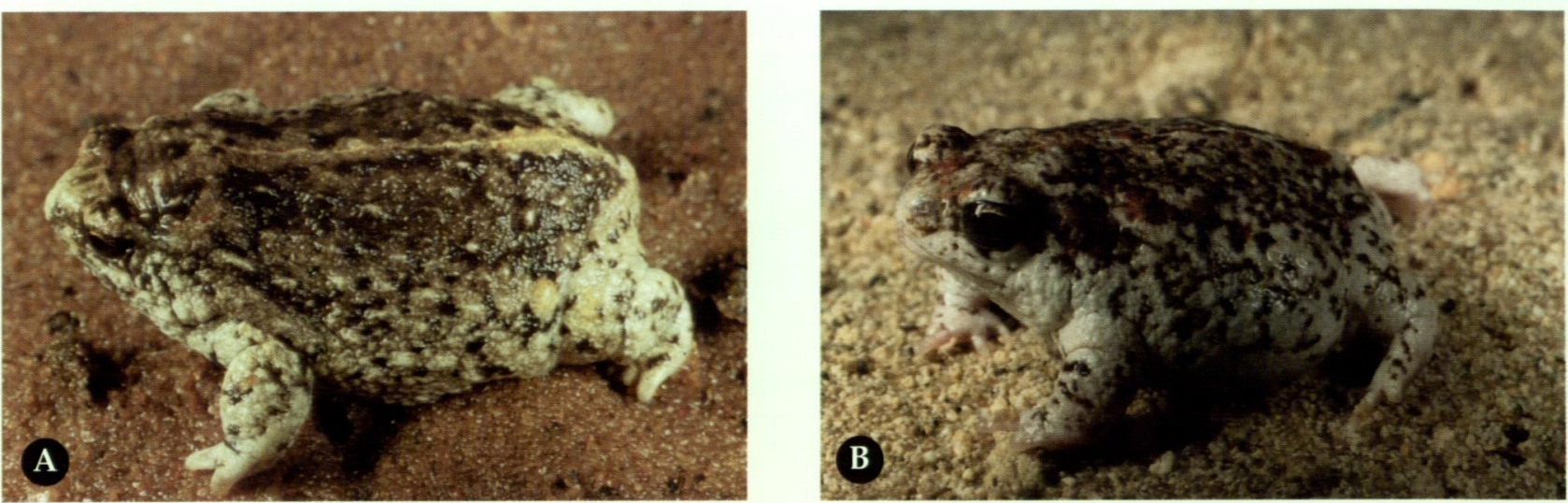

Figure 2 A, Arenophryne xiphorhyncha sp. nov. from type location (Coolomia Station, Western Australia); B, A. rotunda also from the type location (False Well Entrance, Shark Bay, Western Australia). Photographs by Brad Maryan.

snout. There are usually conspicuous darker paravertebral stripes on the back, along with dark irregular markings. There is a lighter vertebral area with a thin clearly demarcated yellow to cream stripe running from the back of the head to the urostyle where it is more clearly seen. Raised tubercles and folds on the dorsum are often tipped with the pale ground colour. There are often scattered deep red flecks present on the dorsum and some yellow flecks present on the sides, especially near the groin. The belly is pale with stippling or irregular blotching with a semi-translucent abdomen.

\section{Colour in preservative}

Pale to dark brown with irregular light and dark flecking and darker vertebral and paravertebral longitudinal stripes or bands discernible. Head slightly paler than body colour with very pale snout. Thin yellowy vertebral stripe visible on posterior half of dorsum. Red flecks present only on recently-preserved $(<2$ y) specimens. Paravertebral stripes beige to light-brown to blue-grey, from faintly expressed to very dark and conspicuous. Vertebral area between paravertebral stripes ranges from pale background colour to nearly the same darkness as the paravertebral stripes in some specimens. Canthal stripe passes through eye to continue as dorsolateral stripe. Side of head below canthal stripe and eye has the pale ground colour. Dorsolateral stripe ranges from a thin line angled downwards from shoulder to groin with faint stippling below to nearly a solid dark stripe along flank. Forelimbs and hands pale. Rear thigh and tibia same as dorsal colouration, but with pale feet (as for forelimbs and hands). Belly patterns were variably stippled with black, but in general the pattern was for a pale background upon which was darker stippling ranging from diffuse to markedly blotched. Stippling was concentrated in the center of the belly and faded distally towards the head, flanks and legs.

\section{Etymology}

The specific name is a Latinized version of the Greek xiphos (sword) + rhynchos (nose or snout) in reference to the sharper snout of $A$. xiphorhyncha compared to $A$. rotunda. For common names, we suggest for A. xiphorhyncha the "southern sandhill frog" and for $A$. rotunda the "northern sandhill frog".

\section{Comparisons with other species}

Arenophryne xiphorhyncha occurs near four other myobatrachid frogs on the central western coast. Although the call of $A$. xiphorhyncha is not known, many myobatrachids have very similar calls consisting of a short harsh rasp, including $A$. rotunda, Myobatrachus gouldii, Metacrinia nichollsi, all Pseudophyrne Fitzinger, 1841 and many Uperoleia Gray, 1841 (Roberts 1984). We anticipate that $A$. xiphorhyncha will have a similar call, although this remains to be documented.

Pseudophryne guentheri is known from the area and can be distinguished from A. xiphorhyncha by the following traits: body much less stout, snout and eyes more prominent, longer and more slender limbs with long fingers and toes, large metatarsal tubercles, often large dark blotches on back, backwards burrowing, lays eggs. Pseudophyrne occidentalis occurs just to the north and east of the known distribution of $A$. xiphorhyncha. In addition to the characters listed for $P$. guentheri, $P$. occidentalis also has an orange patch on the snout between the eyes and usually on the elbows and rump.

Myobatrachus gouldii is known to occur just to the south (Eradu) of $A$. xiphorhyncha. It is distinguished by its pink to yellow skin, more reduced and fusiform head and attains a larger 


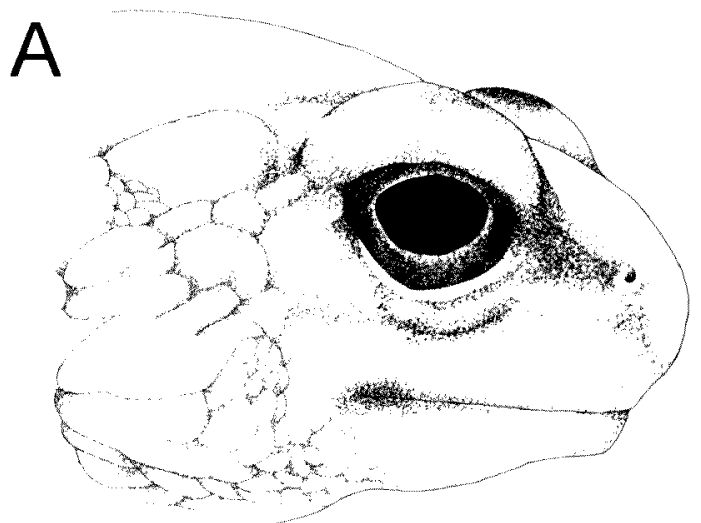

Arenophryne xiphorhyncha

$\mathrm{B}$

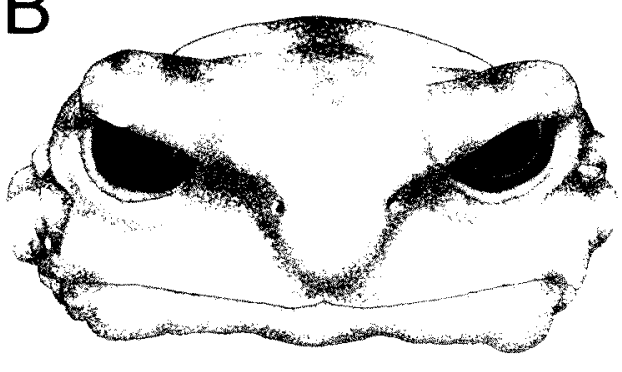

C

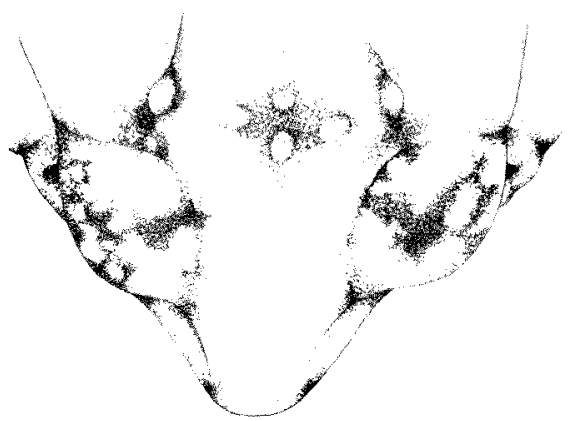

Arenophryne rotunda

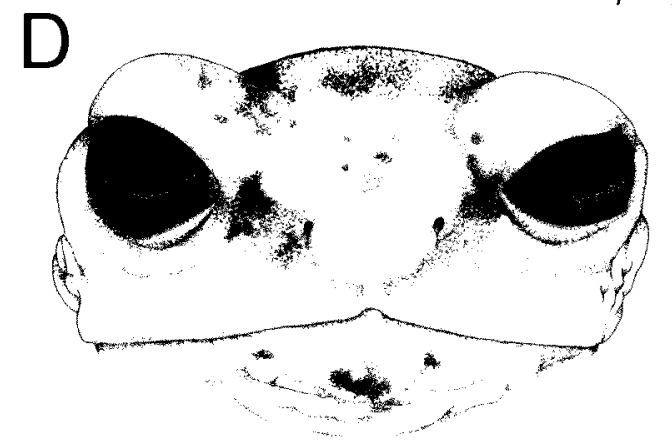

$\mathrm{F}$

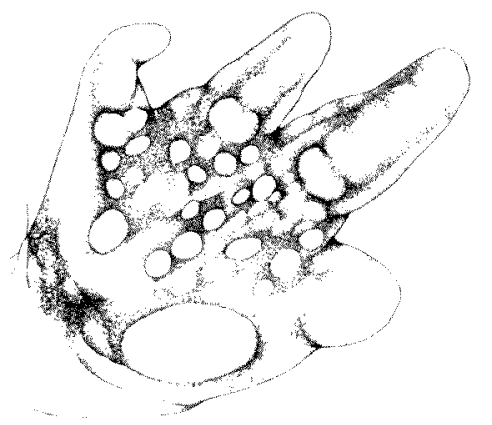

E

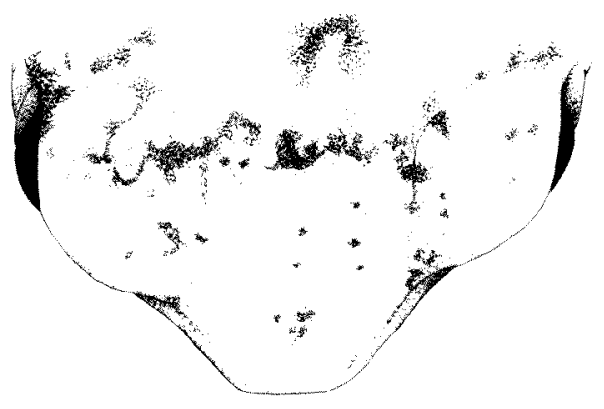

G

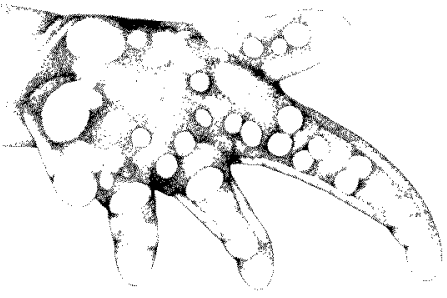

Figure 3 Diagrams of the lateral view of the head $(A)$, anterior view (B), dorsal view $(C)$, hands $(F)$ and feet $(G)$ of the holotype (WAM R67321) of Arenophyrne xiphorhyncha sp. nov. Anterior (D) and dorsal (E) views of the head of $A$. rotunda are provided for comparison (WAM R68348) 
body size $(50 \mathrm{~mm}$ vs. $30 \mathrm{~mm}$ SVL in A. xiphorhyncha).

Arenophyrne xiphorhyncha differs from its congener $A$. rotunda by, in general, possessing traits indicating a stronger commitment or history of burrowing habits. The head of $A$. xiphorhyncha is more streamlined including smaller and less protruding eyes, shorter distances between the eyes and nostrils, and a sharper snout. The hands of $A$. xiphorhyncha are larger, have more tubercules and the ridges on the sides of the hand are more developed than those of $A$. rotunda. The colouration of $A$. xiphorhyncha is much darker than that of $A$. rotunda (Figure 2 ).

\section{Habitats, feeding and breeding biology}

Arenophryne xiphorhyncha inhabits sandy regions within the Geraldton sandplain. Frogs presumably shelter underground during the day, and emerge at night to feed on the surface at suitable times of the year (autumn - spring). Observations of gut contents of preserved specimens were entirely of ants, but more detailed analyses may yield a wider range of prey types.

Nothing specific is known of the breeding biology of $A$. xiphorhyncha, although the breeding biology of $A$. rotunda is moderately well-known (Roberts 1984; Anstis et al. 2007). In A. rotunda, males call in late winter and spring in response to rain. Pairs form and spend the summer together when frogs are inactive owing to high temperatures and lack of rain. Eggs are deposited in autumn in about $80 \mathrm{~cm}$ of sand and hatch over two months later.

All previous reports of the biology of Arenophryne have been on $A$. rotunda from Shark Bay. Presumably, many of the habits, ecology and breeding biology of $A$. xiphorhyncha will be similar to $A$. rotunda, but further studies need to be conducted to test this supposition.

\section{Distribution}

Arenophryne xiphorhyncha is only known from a broad strip of sandplain north of Geraldton and south of Shark Bay, Western Australia (Figure 1). The distance between the northern and southernmost locality records is approximately $120 \mathrm{~km}$. It is worth noting that the description of the southern Arenophryne as a separate species reduces the range of true $A$. rotunda considerably. Arenophryne rotunda is now confined to the white coastal dunes from the northern tip of Dirk Hartog Island to near the base of the Edel Land peninsula approximately $150 \mathrm{~km}$.

\section{DISCUSSION}

The detection of a second species within Arenophyrne based on molecular genetic results and subtle morphological differences between the species indicates that there could be other cryptic species of frogs and reptiles that show reduction of morphological traits owing to adaptations for burrowing in sand. For example, species in the gekkonid genus Aprasia are subterranean burrowers that inhabit the coastal sands in southwestern Australia up to the Pilbara region. Recent morphological and genetic research has revealed many cryptic species within these forms (B. Maryan, K. Aplin and M. Adams, unpublished data). Western heath dragons (genus Rankinia Wells and Wellington, 1985) also exhibit an affinity to isolated sandy habitats in the southwest (including the unique ability within Australian dragons to "shimmy-bury" in the sand - Greer 1989). Western heath dragon populations showing deep historical divergences genetically (Melville and Doughty in press). However, the sister group to Arenophryne - the obligate sand-dwelling forwards-burrowing turtle frogs (Myobatrachus gouldii) - are distributed over a much wider area in southwestern Australia, but do not exhibit significant breaks in phylogeographic structure over their range (S. Keogh, P. Doughty, M. Adams and D. Edwards, unpublished data).

Climate induced sea level fluctuations during the Plio-Pleistocene, resulting in coastal dune evolution in the region (Hocking et al. 1987), have been hypothesised as drivers of speciation within herpetofauna of the Shark Bay and wider Carnarvon Basin region (Storr and Harold 1980; Rabosky et al. 2004). Fluctuating sea levels are plausible explanations for vicariance in species with disjunct populations across the northern Carnarvon Basin, such as Rankinia (Melville and Doughty, in press) and several other skink and gecko species (Storr and Harold 1978, 1980). However, divergence estimates dating the split within Arenophryne (Edwards 2007) suggest that speciation predates the PlioPleistocene sea level fluctuations. Molecular clock estimates can be subject to error (Rambaut and Bromham 1998), however, the above date provides an estimate that is correlated with known climatic and geological changes.

The formation of the Victoria Plateau, in combination with sweeping aridity, is likely to have led to the Late Miocene divergence between the two Arenophryne species (Edwards 2007). During the late Miocene, tectonic instability resulted in the reactivation of pre-existing faults and the uplift and formation of the Victoria Plateau, with the Victoria Plateau uplifted by as much as $60 \mathrm{~m}$ in the Kalbarri region (Haig and Mory 2003). The northern border of the Victoria Plateau corresponds to the geographic position of the genetic break between the two Arenophryne species. The thick coastal sand deposits of the Edel group (common in the area today) were not 
formed until the Plio-Pleistocene (Hocking et al. 1987), therefore an alternative avenue for dispersal would not have been available for obligate sanddwelling forms.

The current distribution of $A$. rotunda is restricted to the coastal white sand dunes along the Edel and Shark Bay Peninsulas, while the distribution of $A$. xiphorhyncha covers much more variable in soil types (Figure 1). South of the Murchison Gorge, populations occur on black sandplain. Immediately north of the Murchison Gorge and up to the Zuytdorp coastal region, populations occur on yellow sandplain. Further inland of the Zuytdorp coast and up into the Cooloomia region, populations occur on siliceous red sandplain and dune systems. The morphological differences between $A$. rotunda and $A$. xiphorhyncha may be representative of a history tied to coastal sands (in the case of $A$. rotunda) as opposed to a history tied to sandplain complexes (in the case of $A$. xiphorhyncha).

When considering the morphology and appearance of $A$. xiphorhyncha with its close relatives, it appears to be intermediate between $A$. rotunda and $M$. gouldii in its commitment to burrowing habits. Although $A$. rotunda is a fully subterranean species like the other two, it retains a more globular "frog-like" appearance. In contrast, A. xiphorhyncha has a smaller head with smaller less protruding eyes, shorter distances between all facial distances (Table 2) and a sharper canthus, all of which present a smaller surface area when pushing forwards through the sand. Morphological differences between the two Arenophryne species may have evolved in response to the relative difficulty of pushing through the heavier yellow and red calcareous sands of the Geraldton sandplain in the case of $A$. xiphorhyncha compared to the lighter coastal sand dunes that $A$. rotunda inhabits. In $M$. gouldii the trend for evolution of a fusiform shape is even more extreme, with the head and eyes extremely reduced producing a bizarre appearance for a frog, and providing it with its common name - the turtle frog. In addition to differences in the head, the hands of $A$. xiphorhyncha were significantly larger than those of $A$. rotunda, presumably to provide a larger surface area for pushing sand out of the way during forwards burrowing; $M$. gouldii has even larger hands continuing this trend (see Davies 1984 Figure 11), and all three species have a reduced $4^{\text {th }}$ finger to produce a broad spatulate hand (Davies 1984). Colouration also varies markedly between the Arenophryne species, with the pale ground colour of $A$. rotunda matching the white sands of Shark Bay, while A. xiphorhyncha's darker brown colour matches the darker calcareous sands within the Geraldton Sandplain (Figure 1). The pink to yellow pigmentation of $M$. gouldii is likely due to less time spent on the surface, and hence less need for the ground colour to match the substrate background to avoid predation by visually-oriented predators.

The evolutionary precursor to forwardsburrowing through sand may have been the crawling habits of the sister taxon to all three burrowing forms, Metacrinia nichollsi. This species is similar to Pseudophryne in its ground-dwelling habits, including walking or crawling instead of hopping. Metacrina lives in deep leaf litter in southwest Australia, and diving in to this substrate may have led to the development of forwards burrowing in Arenophryne and Myobatrachus. The forwards-burrowing asterophryine and sphenophrynine microhylids of Papua New Guinea also have close relatives that occur in dense leaf litter, supporting this supposition (Menzies and Tyler 1977; Davies 1984). More comparative work on the evolution of forwards-burrowing habits and the attendant morphological adaptations such as reduced head size, reinforced pectoral girdle, increase in arm and hand size, rotation of the angle of the limbs for burrowing and other characters would be a fruitful area of study, especially given its multiple origins within the anurans (Emerson 1976; Menzies and Tyler 1977; Trueb and Canatella 1982).

\section{ACKNOWLEDGEMENTS}

We thank Claire Stevenson for the drawings and map, Brad Maryan for providing the photographs, Alicia Carlisle for help in the laboratory, and Dale Roberts, Glenn Shea and Mike Tyler for helpful discussions.

\section{REFERENCES}

Anstis, M., Roberts, J. D., and Altig, R (2007). Direct development in two myobatrachid frogs, Arenophryne rotunda Tyler and Myobatrachus gouldii Gray, from Western Australia. Records of the Western Australian Museum 23: 259-272.

Cincotta, R. P., Wisnewski, J., and Engelman, R. (2000). Human population in the biodiversity hotspots. Nature 404: 990-992.

Davies, M. (1984). Osteology of the mvobatrachine frog Arenophryne rotunda Tyler (Anuraleptodactylidae) and comparisons with other myobatrachine genera. Australian Journal of Zoology 32: 789-802.

Donnellan, S., Adams, M., Hutchinson, M., and Bayerstock, P. R. (1993). The identification of cryptic species in the Australian herpetofauna: a high research priority (pp. 121-125). In: Lunney, D., and Ayers, D. (eds.) Herpetology in Australia: a diverse discipline. Surrey Beatty \& Sons, Chipping Norton NSW, Australia

Edwards, D. (2007). Biogeography and speciation in a direct developing frog from the coastal arid zone of 
Western Australia. Molecular Phylogenetics and Evolution 45: 494-505.

Emerson, S. B. (1976). Burrowing in frogs. Journal of Morphology 149: 437-458.

Frost D. R., Grant, T., Faivovich, J., et al. (2006) The Amphibian tree of life. Bulletin of The American Museum of Natural History 297: 1-370.

Greer, A. E. (1989). Biology and Evolution of Australian Lizards. Surrey Beatty \& Sons: Sydney.

Haig, D. W. and Mory, A. J. (2003). New record of siliceous, marine, later Eocene from Kalbarri, Western Australia. Journal of the Royal Society of Western Australia 86: 107-113.

Hocking, R. M., Moors, H.T., and Van de Graaff, W. J. E. (1987). Geology of the Carnarvon Basin, Western Australia, 289 pp. Geological Survey of Western Australia: Perth.

Hopper, S. D., and Gioia, P. (2004). The Southwest Australian Floristic Region: Evolution and Conservation of a Global Hot Spot of Biodiversity. Annual Review of Ecology, Evolution and Systematics 35: 623-650.

Hopper, S. D., Harvey, M. S., Chappill, J. A., Main, A. R., and York Main. B. (1996). The Western Australian biota as Gondwanan heritage - a review (pp. 1-46). In: Hopper, S. D., Chappill, J. A., Harvey, M. S., and George, A. S. (eds), Gondwanan Heritage: Past, Present and Future of the Western Australian Biota. Surrey Beatty \& Sons: Sydney.

Melville, J., and Doughty, P. (in press). Phylogeography and local endemism of the heath dragons (Rankinia adelaidensis and $R$. parviceps) from the southwestern Australian biodiversity hotspot. Copeia.

Menzies, J. I., and Tyler, M. J. (1977). The systematics and adaptations of some Papuan microhylid frogs which live underground. Journal of Zoology (London) 183: 431-464.

Myers, N., Mittermeier, R. A., Mittermeier, C. G., da Fonseca, G. A. B., and Kent, J. (2000). Biodiversity hotspots for conservation priorities. Nature 403: 853858.

Rabosky, D. L., Aplin, K. A., Donnellan, S. C., and Hedges, S. B. (2004). Molecular phylogeny of blindsnakes (Ramphotyphlops) from Western Australia and resurrection of Ramphotyphlops bicolor (Peters 1857). Australian Journal of Zoology 52: 531-548.
Rambaut, A., and Bromham, L. (1998). Estimating divergence dates from molecular sequences. Molecular Biology and Evolution 15: 442-448.

Read, K., Keogh, J. S., Scott, I. A. W., Roberts, J. D., and Doughty, P. (2001). Molecular phylogeny of the Australian frog Genera Crinia, Geocrinia, and allied taxa (Anura: Myobatrachidae). Molecular Phylogenetics and Evolution 21: 294-308.

Roberts, J. D. (1981). Terrestrial egg deposition and direct development in Arenophryne rotunda Tyler, a myobatrachid frog from coastal sand dunes at Shark Bay, W.A. Australian Wildlife Research 11: 191-200.

Roberts, J. D., and Watson, G. F. (1993). Biogeography and phylogeny of the Anura (pp. 35-40). In: Glasby, C. J., Ross, G. J. B., and Beesley, P. L. (eds.) Fauna of Australia. Australian Government Publishing: Canberra.

Storr, G. M., and Harold, G. (1978). Herpetofauna of the Shark Bay Region, Western Australia. Records of the Western Australian Museum 6: 449-467.

Storr, G. M., and Harold, G. (1980). Herpetofauna of the Zuytdorp Coast and hinterland, Western Australia. Records of the Western Australian Museum 8: 359 375.

Trueb, L., and Cannatella, D. C. (1982). The cranial osteology and hyolaryngeal apparatus of Rhinophrynus dorsalis (Anura:Rinophrynidae) with comparisons to recent pipid frogs. Journal of Morphology 171: 11-40.

Tyler, M. J. (1976). A new genus and two new species of leptodactylid frogs from Western Australia. Records of the Western Australian Museum 4: 45-52.

Tyler, M. J. (1994). Australian Frogs: A Natural History. Cornell University Press, Ithaca, New York.

Tyler, M. J., Roberts, J. D., and Davies, M. (1980). Field observations on Arenophryne rotunda Tyler, a leptodactylid frog of coastal sandhills. Australian Wildlife Research 7: 295-304.

Manuscript accepted 6 July 2007. 


\section{APPENDIX}

Comparative material examined. All specimens from the Western Australian Museum, Welshpool (R prefix omitted below).

\section{Arenophryne xiphorhyncha}

Females - 66444, 121780, 123495, 123497, 123499, 123500, 126244, 126246, 126254, 126259, 126271, 126272 , $126288,165822$.

Males - $123550,123560,126262,126267,126278$.

\section{Arenophyrne rotunda}

Females - 55206, 68350, 114066, 114083, 114084, 122520, 126156, 126158, 126159, 146480, 157824, 157825, $157826,157828,157831,157832,157833,157834,165796,165804,165805,165806,165809$.

Males - $\quad 68348,68349,87852,87853,165803,165808,165810$. 